Pesq. Vet. Bras. 36(10):939-946, outubro 2016 DOI: 10.1590/S0100-736X2016001000004

\title{
Epidemiological survey of Neorickettsia risticii in equids from the State of Rio de Janeiro, Brazil ${ }^{1}$
}

\begin{abstract}
Erica C.R. Roier ${ }^{2}$, Renata L. Costa ${ }^{3}$, Marcus S. Pires ${ }^{3}$, Joice A.R. Vilela ${ }^{4}$, Tiago M. dos Santos ${ }^{5}$, Huarrisson A. Santos ${ }^{5}$, Cristiane D. Baldani ${ }^{6}$ and Carlos L. Massard ${ }^{7 *}$

ABSTRACT.- Roier E.C.R., Costa R.L., Pires M.S., Vilela J.A.R., Santos T.M., Santos H.A., Baldani C.D. \& Massard C.L. 2016. Epidemiological survey of Neorickettsia risticii in equids from the State of Rio de Janeiro. Pesquisa Veterinária Brasileira 36(10):939-946. Departamento de Parasitologia, Universidade Federal Rural do Rio de Janeiro, BR-465 Km 7, Seropédica, RJ 23890-000, Brazil. E-mail: carlosmassard@ufrrj.br

Equine neorickettsiosis (EN), also known as Potomac Horse Fever, is a non-contagious disease caused by the bacterium Neorickettsia risticii of the Anaplasmataceae family. The objectives of this study were to detect the presence of anti- $N$. risticii antibodies by the indirect immunofluorescence assay (IFA) and of its DNA by qPCR in equids at high and low altitude regions in the State of Rio de Janeiro, Brazil, and to identify factors associated with seropositive equids by multiple logistic regression analysis. The frequency of anti- $N$. risticii antibodies was $16.05 \%(n=113 / 704)$. The animal age and breeding region were the factors that influenced the seropositivity rate for $N$. risticii in the equids $(\mathrm{p}<0.05)$. Equids from the lowland region had higher seropositivity $(\mathrm{p}<0.05 ; \mathrm{OR}=5.87)$ compared to those of the mountain region. The presence of snails on the farm was a factor associated with this result $(\mathrm{p}<0.05$; $O R=2.88)$. In the lowland region, age of the animal and site of breeding were protective factors for the detection of antibodies anti- $N$. risticii in equids, with lower frequency of seropositivity in younger animals $(\mathrm{p}<0.05$; $\mathrm{OR}=0.06)$ and in animals raised in dry areas $(\mathrm{p}<0.05$; $\mathrm{OR}=0.22)$. The presence of the target DNA of $N$. risticii by qPCR was not observed in any of the samples tested. The existence of seropositive equids for $N$. risticii demonstrates a possible circulation of this agent in the studied area, and that the age related characteristics and equids breeding region are important factors regarding seropositivity in the State of Rio de Janeiro.
\end{abstract}

INDEX TERMS: Neorickettsia risticii, equids, Rio de Janeiro, equine monocytic ehrlichiosis, serological diagnosis, epidemiology.

RESUMO.- [Levantamento epidemiológico de Neorickettsia risticii em equídeos do Estado do Rio de Janeiro.] A Neorickettisiose equina (NE), também conhecida como

\footnotetext{
${ }^{1}$ Received on December 3, 2015.

Accepted for publication on June 1, 2016.

${ }^{2}$ Departamento de Medicina Veterinária, Universidade Severino Sombra (USS), Vassouras, RJ, Brazil.

${ }^{3}$ Programa de Pós-Graduação em Ciências Veterinárias, Departamento de Parasitologia, Universidade Federal Rural do Rio de Janeiro (UFRRJ), BR-465 Km 7, Seropédica, RJ 23890-000, Brazil.

${ }^{4}$ Empresa de Assistência Técnica e Extensão Rural (Emater), Estrada RJ-99 Km 8, Piranema, Itaguaí, RJ 23.855-120, Brazil.

${ }^{5}$ Departamento de Epidemiologia e Saúde Pública, UFRRJ, BR-465 Km 7, Seropédica, RJ 23890-000, Brazil.

${ }^{6}$ Departamento de Medicina e Cirurgia Veterinária, UFRRJ, BR-465 Km 7, Seropédica, RJ 23890-000, Brazil.

${ }^{7}$ Departamento de Parasitologia, UFRRJ, BR-465 Km 7, Seropédica, RJ 23890-000. *Corresponding author: carlosmassard@ufrrj.br
}

Febre do Cavalo de Potomac, é uma doença não contagiosa causada pela bactéria Neorickettsia risticii da família Anaplasmataceae. Os objetivos deste estudo foram detectar a presença de anticorpos anti- $N$. risticii através da reação de Imunofluorescência Indireta (RIFI) e do DNA dessa bactéria através da qPCR em equídeos de regiões de alta e baixa altitude no Estado do Rio de Janeiro, Brasil; e identificar os fatores associados com a soropositividade dos equídeos através da análise de regressão logística múltipla. A frequência de anticorpos anti- $N$. risticii foi de 16,05\% ( $\mathrm{n}=113 / 704)$. Observou-se que a idade e a região de criação foram os fatores que influenciaram a taxa de soropositividade para $N$. risticii nos equídeos $(\mathrm{p}<0,05)$. Equídeos da região de baixada apresentaram maior soropositividade $(p<0,05$; $\mathrm{OR}=5,87$ ) quando comparado aos criados em região de montanha. A presença de caramujos na propriedade foi um fator associado a este resultado $(p<0,05 ; 0 R=2,88)$. $\mathrm{Na}$ 
região de baixada, animais mais jovens $(\mathrm{p}<0,05 ; \mathrm{OR}=0,06)$, criados em áreas secas $(\mathrm{p}<0,05 ; \mathrm{OR}=0,22)$ demonstraram serem fatores de proteção na detecção de anticorpos anti- $N$. risticii. Não foi observada a presença do DNA-alvo de $N$. risticii através da qPCR em nenhuma das amostras testadas. A existência de equídeos soropositivos para $N$. risticii demonstra a possível circulação desse agente na área estudada, e as características inerentes a idade e a região de criação dos equídeos são fatores importantes relacionados à soropositividade no estado do Rio de Janeiro.

TERMOS DE INDEXAÇÃO: Neorickettsia risticii, equídeos, Rio de Janeiro, Erliquiose Monocítica Equina, diagnóstico sorológico, epidemiologia.

\section{INTRODUCTION}

Equine neorickettsiosis (EN), also known as Potomac Horse Fever, is a non-contagious infectious disease that affects equines and has as etiological agent Neorickettsia risticii, previously described as Ehrlichia risticii (Holland et al. 1985, Dumler et al. 2001, Pusterla et al. 2013). This microorganism has affinity for monocytes, but also affects other cells, especially of the colon intestinal epithelium, mastocytes and macrophages (Rikihisa et al. 1984, Oliver \& Stampfli 2006).

The infection in equines may cause a severe disease with signs and symptoms of depression, fever, anorexia, enteritis, watery diarrhea, colic and laminitis, and fatality rate of the affected animals of up to 30\% (Knowles et al. 1983, Holland et al. 1985, Palmer 1993). Abortion cases in mares caused by $N$. risticii infection have been described (Long et al. 1995, Coffman et al. 2008). However, serological studies indicate that up to $33 \%$ of seroreactive equines for the bacteria may not develop the disease characteristic clinical conditions (Goetz et al. 1989, Rikihisa et al. 1990, Olchowy 1990, Palmer 1993).

Studies demonstrate the possibility of this infection occur in other mammals, such as goats, dogs, cats, sheep and cattle, however, their role in the epidemiological cycle remains unclear (Perry et al. 1989, Pusterla et al. 2001). The $N$. risticii transmission to equines occurs orally, by accidental ingestion of infected trematodes (Palmer \& Benson 1988). These trematodes use intermediate hosts such as limnic molluscs and aquatic insects, which may be present in the water or pastures, favoring the accidental ingestion by equines (Barlough et al. 1998, Mott et al. 2002, Pusterla et al. 2003, Gibson et al. 2005).

The diagnosis of EN is performed by clinical symptomatology and serological tests, among them, the indirect immunofluorescence assay (IFA), enzyme-linked immunosorbent assay (ELISA) and western immunoblotting (Holland et al. 1985, Dutta et al. 1985). However, many studies indicate the IFA as standard test for diagnosing this agent, because its practicality and specificity (Rikihisa \& Perry 1984, Holland et al. 1985, Dutta et al. 1987). This method stands out as one of the main tests used in epidemiological studies on N. risticii (Atwill et al. 1992, Kipper et al. 1992, Atwill et al. 1994, 1996).

The isolation of the microorganism can be performed by cell cultures and inoculation in laboratory animals (Chae et al. 2002). Moreover, the use of molecular techniques such as PCR has been drawn attention as a $N$. risticii detection in equine blood samples (Biswas et al. 1994, Mott et al. 1997), as well as in tissue samples from invertebrate hosts involved in this agent transmission chain (Barlough et al. 1998). Quantitative PCR (qPCR) has been used in molecular detection of different classes of pathogen microorganisms in humans and animals (Espy et al. 2006), and developed protocols for target genes present in $N$. risticii already exists (Pusterla et al. 2000, 2006).

Studies related to infection by $N$. risticci indicate a greater incidence of the disease in the summer (Atwill et al. 1992, Goetz et al. 1989, Olchowy 1990). The presence of large valleys containing rivers, lowland areas with ponds or irrigation furrows in the equine breeding area also appear to be factors associated with the disease occurrence (Palmer et al. 1986, Madigan et al. 1997, Dutra et al. 2001). Moreover, the animal race, animal age and gender were indicated as factors related to disease cases (Atwill et al. 1992).

In Brazil, the exposure of equines to $N$. risticii has been reported in the State of Rio Grande do Sul, through molecular and serological tests (Dutra et al. 2001, Coimbra et al. 2006). Serological evidences also indicate the agent circulation among equines of the State of Rio de Janeiro, Sao Paulo and Santa Catarina (Ferrão et al. 2007, Moreira et al. 2013). However, there are few studies in Brazil and in the State of Rio de Janeiro addressing in detail the epidemiological aspects related to the agent infection and circulation among equines. This information is required for the adoption of preventive measures and control of this important disease in equines.

Thus, the objectives of this study were to detect the presence of anti- $N$. risticii antibodies by indirect immunofluorescence assay (IFA) and of this its DNA by qPCR in equids at high and low altitude regions in the State of Rio de Janeiro, Brazil, and identify factors associated with the frequency of seropositive equines for $N$. risticcii.

\section{MATERIALS AND METHODS}

Description of the studied regions. The study was conducted in properties with equine breeding in two regions of the State of Rio de Janeiro, a mountain (micro-region of Serrana) and a lowland region (micro-region of Itaguai). Three municipalities were selected in the lowland region: Itaguai $\left(22^{\circ} 51^{\prime} 08^{\prime \prime} \mathrm{S}, 43^{\circ} 46^{\prime} 31^{\prime} \mathrm{W}\right.$ and altitude of $13 \mathrm{~m}$ ), Mangaratiba (22 $57^{\prime} 36^{\prime \prime} \mathrm{S}, 44^{\circ} 02^{\prime} 27^{\prime \prime} \mathrm{W}$ and altitude of $18 \mathrm{~m}$ ) and Seropedica (22 $44^{\circ} 38^{\prime \prime} \mathrm{S}, 43^{\circ} 42^{\prime} 27^{\prime \prime} \mathrm{W}$ and altitude of $26 \mathrm{~m}$ ), and two in the mountain region, Petrópolis (22 $30^{\prime} 18^{\prime \prime} \mathrm{S}, 43^{\circ} 10^{\prime} 44^{\prime \prime} \mathrm{W}$ and altitude of $809 \mathrm{~m}$ ) and Teresópolis ( $22^{\circ} 24^{\prime} 43^{\prime \prime} \mathrm{S}, 42^{\circ} 57^{\prime} 57^{\prime \prime} \mathrm{W}$ and altitude of $\left.910 \mathrm{~m}\right)$. The lowland region climate is characterized as tropical, with a dry season and rainy summer (Aw) and the mountain region climate as humid temperate with dry winter and temperate summer (Cwb), according to the classification of Köppen (Pieel et al. 2007).

Sampling. The sample size was determined establishing a confidence level of 95\%, an expected prevalence of 33\% for $\mathrm{NeO}$ rickettsia risticii (Moreira et al. 2013) and an error margin of 5\%, according to the formula described by Sampaio (2002). The minimum number of equids established to sample collection in each region was 340 . Sampling was performed by convenience, collec- 
ting 350 samples in the lowland and 354 in the mountain region, totaling 704 animals (692 equines and 12 mules).

In each selected property that had equids sampled, the altitude was recorded and the points georeferenced with Global Positioning System receivers (GPS). The reference system used was the South American Datum 1969 (SAD69). The software ARC GIS ${ }^{\circledR} 9$ ESRI was used to generate the location map of the studied area (Fig.1).

Sample collection and molecular and serological diagnostic. Serum samples collected from each animal were subjected to the IFA for detection of anti- $N$. risticii antibodies (IgG), using the diagnostic kit (Fuller Laboratories ${ }^{\circledR}$, USA), with positive control serum, phosphate buffered saline (PBS) solution as a negative control and anti-IgG. Serum samples with titers $\geq 1: 50$ were considered positive. Reactions were performed according to the manufacturer's recommendations.

Whole blood samples were collected from each animal and subjected to DNA extraction using $300 \mu \mathrm{L}$ in the Wizard Genomic DNA Purification Kit (Promega ${ }^{\circledR}$, Madison, USA), following the manufacturer's recommendations. The DNA samples were resuspended in $100 \mu \mathrm{l}$ of Tris-EDTA (TE), quantified in a Nanodrop ${ }^{\circledR}$ ND-2000 spectrophotometer (NanoDrop Technologies, DE, USA), aliquoted at a concentration of $100 \mathrm{ng} / \mu \mathrm{l}$ and stored at $-80^{\circ} \mathrm{C}$ to later analysis.

The equine DNA samples were analyzed by qPCR aiming the amplification of an $85 \mathrm{bp}$ fragment of the gene 16S RNA-ribosomal present in the species $N$. risticii. The reactions were performed using the qPCR system StepOnePlus ${ }^{\circledR}$ (Applied Biosystems). The threshold was standardized with the obtained plates, manually as- signing from the third cycle after the base fluorescence. The samples that presented quantification cycle $(\mathrm{Cq})$ less than or equal to 40 cycles were considered positive. This analysis was performed using the primers 133f (5'-GTTATTCCCTACTACCAGGCAAGTTC-3') and 54r (5'-AACGGAATCAGGGCTGCTT-3') and probe (5'ACGCACCCGTCTGCCACGGGA 3') (Pusterla et al. 2000) marked with the reporter dye FAM at the $5^{\prime}$ end and with quencher TAMRA at the 3 ' end. The final reaction volume was $20 \mu \mathrm{L}$ containing: $10 \mu \mathrm{L}$ TaqMan (1x), $0.6 \mu \mathrm{M}$ of each primer, $0.2 \mu \mathrm{M}$ of probe and $100 \mathrm{ng}$ of total DNA. The thermocycling conditions were: 2 minutes at $50^{\circ} \mathrm{C}$, 10 minutes at $95^{\circ} \mathrm{C}$ and 45 denaturation cycles at $95^{\circ} \mathrm{C}$ for $15 \mathrm{sec}-$ onds and annealing-extension at $60^{\circ} \mathrm{C}$ for 1 minute. The positive control of the reaction was obtained by DNA extraction from infected cells by $N$. risticii, present in the IFA laminae used in the study. Ultrapure water was used as a negative control.

Epidemiological questionnaire. A semi-structured questionnaire was applied to the property owners in order to identify possible factors associated with equids positivity for N. risticii. The analysis included the breading region (lowland or mountain); property conditions (poor, moderate, good, or excellent), breeding system (intensive, semi-intensive or extensive); contact with other farm animals (presence of cattle, goats, pigs and sheep or no close animals); animal birth origin (born within or outside the property); animal source origin (State of Rio de Janeiro or outside the State/unknown); equids activity (sport/exhibition, recreation/breeding or Farming); gender (male or female); age $(\leq 1$, $>1 \leq 5,>5 \leq 10$ or $>10$ years old); animal breed (defined or mixed breed); presence of snails on the property (yes or no); animal pas-

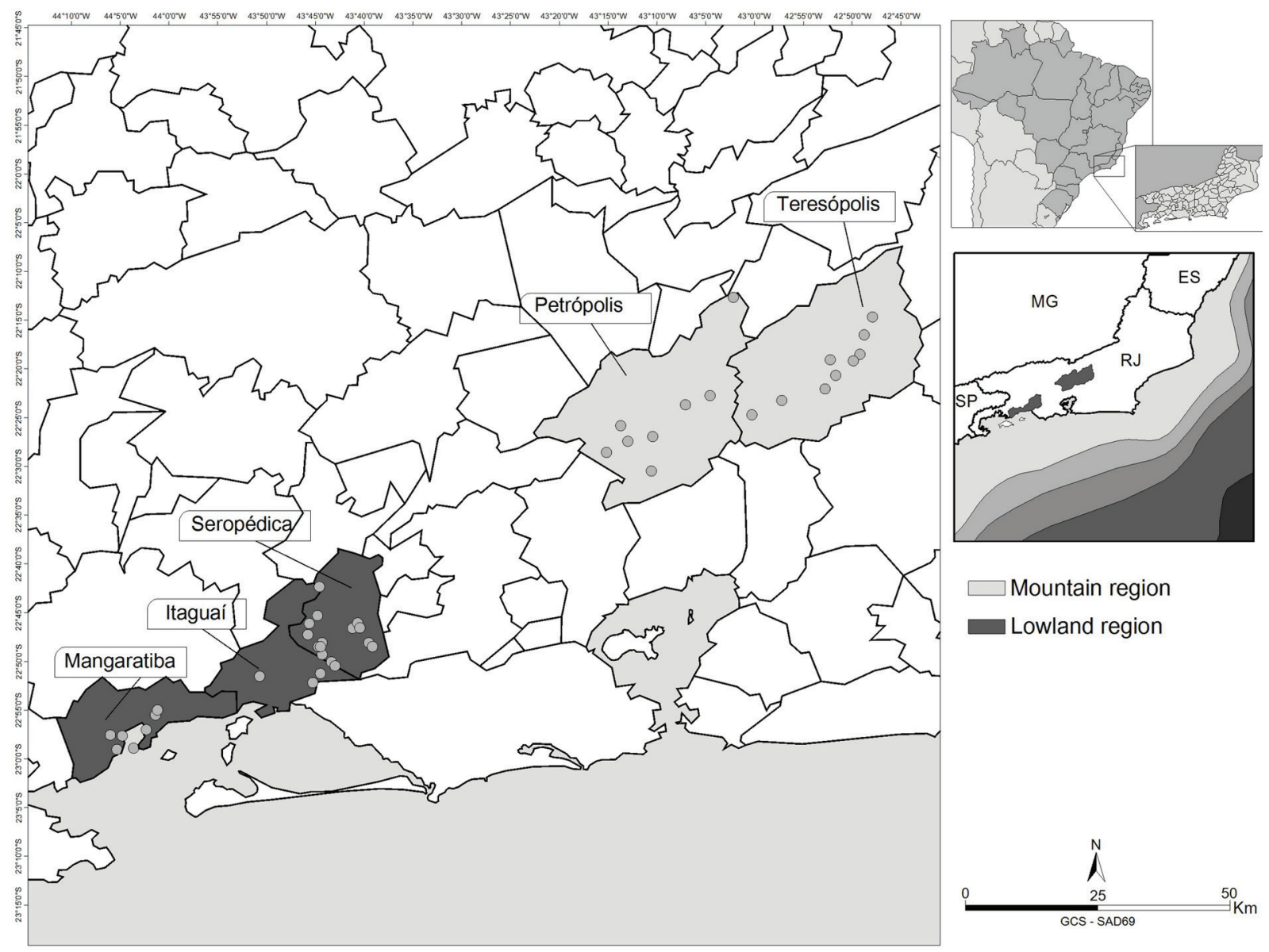

Fig.1. Geographic location of collection sites in the lowland (Itaguaí, Mangaratiba and Seropédica) and in the mountain region (Petrópolis and Teresópolis) in the State of Rio de Janeiro. 
ture characteristic (dry, few flooded areas, many flooded areas or presence of rivers, streams and ponds). Information related to the history of clinical suggestive signs of EN were also investigated, such as the presence of equids with history or signs of diarrhea and colic, laminitis or sensitivities and limb edema, and the presence of equids with fever/depression.

Statistical analysis. The frequency of anti-N. risticii antibodies in the equids was evaluated according to the independent variables and compared using the chi-square $\left(\chi^{2}\right)$ and/or Fisher's exact tests, at $20 \%$ of significance level. Variables that had association $(\mathrm{p}<0.20)$ in the univariate analysis were included for multiple logistic regression model at $5 \%$ significance level. Multivariate analysis was performed using the Stepwise method, and the final model was assessed by the Hosmer and Lemeshow test ( $p>0.05$ ). This analysis was performed for the total of studied equids, as well as for the sub-total of each selected region in the study (mountain and lowland). The R program (R Development Core Team, 2010) was used for statistical analysis.

A descriptive analysis of the data on seroreactive animals and/or infected was performed regarding the presence of clinical signs suggestive of EN.

Institutional ethical license. These procedures were approved by the Ethics Committee on Research of the Federal Rural University of Rio de Janeiro, under protocol number 364/2013 and process number 23083.003989/2013-69.

\section{RESULTS}

The frequency of seroreactive equids for $N$. risticii in the total studied area was $16.05 \%(\mathrm{n}=113 / 704)$, with seropositivity of $16.18 \%$ ( $n=112 / 692)$ in equines and $8.33 \%$ $(n=1 / 12)$ in mules. Seven independent variables presented statistical association $(\mathrm{p}<0.20)$ with the presence of anti$-N$. risticii antibodies in equids (Table 1). However, after the logistic regression analysis, the breeding region and the animal age had the highest associations with the equids seropositivity (Table 2).

Equids bred in the lowland region were 5.87 fold more likely $(\mathrm{p}<0.01)$ being seroreactive for $N$. risticii compared to the ones bred in the mountain region in the state of Rio de Janeiro. This result is reinforced by the higher frequency of seropositivity of equids in the lowland $(26.29 \%$; 92/350), compared to the mountain region $(5.93 \% ; 21 / 354)$. Moreover, animals up to one year old were $95 \%$ less likely $(\mathrm{p}<0.01)$ to be seroreactive for $N$. risticii $(1.61 \% ; 1 / 62)$ compared to older equids in all selected sub-categories $(>1,>5$ and $>10$ years old), showing that the increase of risk of contact with the agent is direct related to the time, the longer the equine live, the higher the chance of contact with the agent (Table 2).

According to the univariate analysis on the animals in each region, in the mountain region, the contact with other farm animals on the property, breeding type, pasture characteristics, animal activity, animal birth origin, age, breed and the animal source origin, were associated $(\mathrm{p}<0.20)$ with equids seropositivity against $N$. risticii. However, there was no association of these factors after multivariate analysis (data not shown). The significant results of the variables in the regression model of the seropositive equids for $N$. risticii in the lowland region, showed that the presence of snails, animal pasture characteristic and animal age were factors associated $(\mathrm{p}<0.05)$ with seropositivity of animals $(\mathrm{p}<0.05)$ differently from the results found in the mountain region (Table 3). Equids bred in properties with the presence of snails were 2.88 fold more likely to be seroreactive for $N$. risticii, and those bred in dry pastures, had 78\% less chance of being seroreactive for $N$. risticii compared to those bred in wetlands or with the presence of ponds, rivers or lakes. Similarly to the results found in the multivariate analysis, regardless of the region studied, the animal age was an important factor associated with the equids seropositivity bred in the lowland region $(\mathrm{p}<0.001 ; \mathrm{OR}=0.06$, $\mathrm{CI}=0.01$ to 0.50 ) (Table 3 ).

All regression models obtained were significant $(p<0.01)$ and the quality of the models was satisfactory, as shown by the results of the Hosmer-Lemeshow test ( $p>0.05)$, performed for each model tested.

The Table 4 show the aspects related to the signs suggesting $N$. risticii infection in the evaluated equids depending on the seropositivity of animals. From the 113 seropositive equidae for $N$. risticii, $4.42 \%(n=5)$ had at least one of the clinical signs suggesting EN. The equids seropositivity for $N$. risticii could not be related to the clinical signs observed due to the low frequency of these signs.

The molecular test did not amplified the target DNA to $N$. risticii in equids of the studied regions.

\section{DISCUSSION}

Serological evidences shows the circulation of $N$. risticii, with clinical case occurrences found in the South and Southeast regions of Brazil (Coimbra et al. 2005, Ferrão et al. 2007). In the state of Rio de Janeiro, studies have shown variation in frequency of seroreactive equines for Neorickettsia risticii (Ferrão et al. 2007, Moreira et al. 2013). The EN possibly occurs in other regions of the country with similar characteristics of the regions here studied.

Researches have shown that in the USA the prevalence of anti- $N$. risticii antibodies ranges from $7.5 \%$ to $76 \%$ depending on the region, the time of year and the equine population studied (Atwill et al. 1996, Kipper et al. 1992, Gordon et al. 1988, Goetz et al. 1989). The seroprevalence of $N$. risticii has also been reported in Canada, Europe and Australia (Palmer et al. 1986, Breider \& Henton 1987, Rikihisa 1988).

The frequency of seropositive equids observed in the present study was below that obtained in other studies (Olchowy et al. 1990, Crawford \& Dilbeck 1988), however, a similar result was observed by Goetz et al. (1989) with prevalence of $16.75 \%$ of seropositive equines to $N$. risticii in Illinois, through the IFA, and by Rikihisa et al. (1990), with seroprevalence of $19 \%$, without clinical signs of EN.

On the other hand, Gordon et al. (1988) observed seroprevalence of $64.9 \%$ in equines with clinical signs suggesting EN, in the USA. In Brazil, Ferrão et al. (2007) found positivity in $79 \%$ of equines from metropolitan and mountain regions in the State of Rio de Janeiro, with clinical signs suggesting with EN, using the IFA.

The animal age and breeding region of equids were the main factors associated with seropositivity for $N$. risticii. These results were similar to those reported by Madigan et al. (1989), who found a higher prevalence of antibodies in 
Table 1. Univariate analysis of factors associated with the frequency of antiNeorickettsia risticii antibodies in equids of a mountain (Serrana micro-region) and a lowland region (Itaguai micro-region) of the State of Rio de Janeiro

\begin{tabular}{|c|c|c|c|c|c|c|}
\hline \multirow[t]{2}{*}{ Animal characteristics } & \multirow[t]{2}{*}{$\mathrm{N}$} & \multicolumn{3}{|c|}{ Descriptive analysis } & \multicolumn{2}{|c|}{ Univariate analysis } \\
\hline & & $\mathrm{n}$ & $(\%)$ & CI de $95 \%$ & $\chi^{2}$ & $\mathrm{P}$ \\
\hline \multicolumn{7}{|l|}{ Region } \\
\hline Lowland & 350 & 92 & 26.29 & $(21.67-30.90)$ & 54.10 & 0.00 \\
\hline Mountain & 354 & 21 & 5.93 & $(3.47-8.39)$ & & \\
\hline \multicolumn{7}{|c|}{ Property conditions (installation and management) } \\
\hline Poor & 183 & 33 & 18.03 & $(12.46-23.60)$ & & \\
\hline Moderate & 131 & 26 & 19.84 & $(13.02-26.68)$ & 4.01 & 0.25 \\
\hline Good & 269 & 40 & 14.87 & $(10.62-19.12)$ & & \\
\hline Excellent & 121 & 14 & 11.57 & $(5.87-17.27)$ & & \\
\hline \multicolumn{7}{|l|}{ Breeding system } \\
\hline Extensive & 151 & 25 & 16.56 & $(10.63-22.48)$ & 1.59 & 0.45 \\
\hline Semi-intensive & 502 & 83 & 16.53 & $(13.28-19.78)$ & & \\
\hline Intensivo & 51 & 5 & 9.80 & $(1.64-17.97)$ & & \\
\hline \multicolumn{7}{|l|}{ Contact with other farm animals } \\
\hline Yes & 221 & 41 & 18.55 & $(13.43-23.68)$ & 1.49 & 0.22 \\
\hline No & 483 & 72 & 14.91 & $(11.73-18.08)$ & & \\
\hline \multicolumn{7}{|l|}{ Presence of snails on the property } \\
\hline Yes & 104 & 24 & 23.08 & $(14.98-31.17)$ & 4.47 & 0.03 \\
\hline No & 600 & 89 & 14.83 & $(11.99-17.68)$ & & \\
\hline \multicolumn{7}{|l|}{ Animal pasture characteristic } \\
\hline Dry & 172 & 17 & 9.88 & $(5.42-14.34)$ & 10.08 & 0.01 \\
\hline Few flooded areas & 333 & 55 & 16.52 & $(12.53-20.50)$ & & \\
\hline Many flooded areas & 108 & 26 & 24.07 & $(16.01-32.14)$ & & \\
\hline Presence of rivers, streams and ponds & 91 & 15 & 16.48 & $(8.86-24.11)$ & & \\
\hline \multicolumn{7}{|l|}{ Genders } \\
\hline Female & 291 & 53 & 18.21 & $(13.83-22.72)$ & 1.72 & 0.18 \\
\hline Male & 413 & 60 & 14.53 & $(11.13-17.93)$ & & \\
\hline \multicolumn{7}{|l|}{ Age } \\
\hline$\leq 1$ years old & 62 & 1 & 1.61 & $(0.01-4.75)$ & 11.45 & 0.00 \\
\hline$>1 \leq 5$ years old & 175 & 28 & 16.00 & $(10.57-21.43)$ & & \\
\hline$>5 \leq 10$ years old & 272 & 46 & 16.91 & $(12.46-21.37)$ & & \\
\hline$>10$ years old & 195 & 38 & 19.49 & $(13.93-25.05)$ & & \\
\hline \multicolumn{7}{|l|}{ Animal breed } \\
\hline Mixed breed & 251 & 46 & 18.33 & $(13.54-23.11)$ & 1.49 & 0.22 \\
\hline Defined breed & 453 & 67 & 14.79 & $(11.52-18.06)$ & & \\
\hline \multicolumn{7}{|l|}{ Animal birth origin } \\
\hline Born outside the property & 491 & 78 & 15.89 & $(12.65-19.12)$ & 0.03 & 0.85 \\
\hline Born in property & 213 & 35 & 16.43 & $(11.46-21.41)$ & & \\
\hline \multicolumn{7}{|l|}{ Animal source origin } \\
\hline State of Rio de Janeiro & 527 & 74 & 14.04 & $(11.08-17.01)$ & 6.28 & 0.01 \\
\hline Outside the State/Unknown & 177 & 39 & 22.03 & $(15.93-28.14)$ & & \\
\hline \multicolumn{7}{|l|}{ Equids activity } \\
\hline Sport/exhibition & 317 & 47 & 14.83 & $(10.91-18.79)$ & 1.04 & 0.59 \\
\hline Recreation/breeding & 276 & 45 & 16.30 & $(11.95-20.66)$ & & \\
\hline Farming & 111 & 21 & 18.92 & $(11.63-26.21)$ & & \\
\hline TOTAL & 704 & 113 & 16.05 & $(13.34-18.76)$ & - & - \\
\hline
\end{tabular}

$\mathrm{N}=$ number of animals examined by IFA; $\mathrm{n}=$ Number of positive animals; $(\%)=$ Positive percentage; $\chi^{2}=$ chi-square test; $\mathrm{p}=\mathrm{p}$-value; $\mathrm{CI}=$ Confidence interval.

older animals, and Atwill et al. (1992), who found higher seropositivity in animals older than 10 years, with peak of antibodies in the 12 years old. The animals up to one-year-old in the present study had a $5 \%$ chance of seropositivity. These results can be justified by the probability increase of a susceptible host to meet a vector infected by $N$. risticii over time, and attributed to the fact that most of these animals are still breast-feeding, which further limit their contact with pasture or water source with the presence of $N$. risticii vectors.

The association (OR: 5.87; IC: 3.55 to 9.73) of equids breeding in the lowland region with seropositivity for $N$. risticii corroborates the results obtained by Atwill et al. (1994) in
New York, who found occurrence of this agent directly influenced by the altitude of the equine breeding properties, showing that the largest amount of river valleys in low altitude areas favors the presence of $N$. risticii vectors. This result is supported by the present study, in which breeding in pastures not flooded or without the presence of lakes and rivers in the surrounding area showed a protective factor against $N$. risticii.

According to some authors, the access to rivers, lakes, reservoirs and irrigation canals by the animals is a risk factor for infection with N. risticii (Palmer et al. 1986, Madigan et al. 1997, Dutra et al. 2001), due to the contact with intermediate hosts that carry this agent in these environments 
Table 2. Logistic regression model (Stepwise method) of factors associated with the frequency of anti-Neorickettsia risticii antibodies in equids of a mountain (Serrana micro-region) and a lowland region (Itaguaí micro-region) of the State of Rio de Janeiro

\begin{tabular}{|c|c|c|c|c|c|c|c|c|}
\hline \multirow[t]{2}{*}{ Independent Variables } & \multirow[t]{2}{*}{$\mathrm{N}$} & \multicolumn{2}{|c|}{ Positive } & \multicolumn{5}{|c|}{ Multivariate Analysis } \\
\hline & & $\mathrm{n}$ & $(\%)$ & $C(ß)$ & SE & $\mathrm{P}$ & OR & CI 95\% \\
\hline \multicolumn{9}{|l|}{ Region } \\
\hline Lowland & 350 & 92 & 26.29 & 1.77 & 0.25 & 0.00 & 5.87 & $(3.55-9.73)$ \\
\hline Mountain & 354 & 21 & 5.93 & $*$ & $*$ & $*$ & $*$ & $*$ \\
\hline \multicolumn{9}{|l|}{ Age } \\
\hline$\leq 1$ years old & 62 & 1 & 1.61 & -2.83 & 1.02 & 0.00 & 0.05 & $(0.01-0.44)$ \\
\hline$>1 \leq 5$ years old & 175 & 28 & 16.00 & -0.23 & 0.28 & 0.41 & 0.79 & $(0.45-1.38)$ \\
\hline$>5 \leq 10$ years old & 272 & 46 & 16.91 & -0.17 & 0.25 & 0.49 & 0.84 & $(0.51-1.38)$ \\
\hline >10 years old & 195 & 38 & 19.49 & $*$ & $*$ & $*$ & $*$ & $*$ \\
\hline Model constant ** & - & - & - & -2.54 & 0.27 & 0.00 & - & - \\
\hline
\end{tabular}

$\mathrm{N}=$ number of animals; $\mathrm{n}=$ Number of positive animals; $(\%)=$ Positive percentage; $\mathrm{C}(\Omega)=$ Model coefficient; $\mathrm{SE}=$ Standard error; $\mathrm{P}=\mathrm{p}$-value; $\mathrm{OR}=$ Odds Ratio; $\mathrm{CI}=$ Confidence interval. ${ }^{*}$ Reference category. ** Hosmer and Lemeshow test $(\mathrm{p}=0.93)$.

Table 3. Logistic regression model (Stepwise method) of factors associated with the frequency of anti-Neorickettsia risticii antibodies in equids of a lowland region (Itaguaí micro-region) of the State of Rio de Janeiro

\begin{tabular}{|c|c|c|c|c|c|c|c|c|}
\hline \multirow[t]{2}{*}{ Independent Variables } & \multirow[t]{2}{*}{$\mathrm{N}$} & \multicolumn{2}{|c|}{ Positive } & \multicolumn{5}{|c|}{ Multivariate Analysis } \\
\hline & & $\mathrm{n}$ & $(\%)$ & $C(ß)$ & SE & $\mathrm{P}$ & OR & CI $95 \%$ \\
\hline \multicolumn{9}{|c|}{ Animal pasture characteristic } \\
\hline Dry & 172 & 17 & 9.88 & -1.47 & 0.63 & 0.02 & 0.22 & $(0.06-0.78)$ \\
\hline Few flooded áreas & 333 & 55 & 16.52 & 0.35 & 0.37 & 0.33 & 1.42 & $(0.69-2.94)$ \\
\hline Many flooded areas & 108 & 26 & 24.07 & * & * & $*$ & $*$ & $*$ \\
\hline $\begin{array}{l}\text { Presence of rivers, } \\
\text { streams and ponds }\end{array}$ & 91 & 15 & 16.48 & -0.18 & 0.40 & 0.65 & 0.83 & $(0.37-1.84)$ \\
\hline \multicolumn{9}{|c|}{ Presence of snails on the property } \\
\hline Yes & 104 & 24 & 23.08 & 1.06 & 0.39 & 0.01 & 2.88 & $(1.33-6.24)$ \\
\hline No & 600 & 89 & 14.83 & * & * & $*$ & $*$ & $*$ \\
\hline \multicolumn{9}{|l|}{ Gender } \\
\hline Female & 152 & 46 & 30.3 & 0.39 & 0.26 & 0.13 & 1.48 & $(0.88-2.50)$ \\
\hline Male & 198 & 46 & 23.2 & $*$ & $*$ & $*$ & $*$ & $*$ \\
\hline \multicolumn{9}{|l|}{ Age } \\
\hline$\leq 1$ years old & 62 & 1 & 1.61 & -2.71 & 1.04 & 0.00 & 0.06 & $(0.01-0.50)$ \\
\hline$>1 \leq 5$ years old & 175 & 28 & 16.00 & -0.21 & 0.33 & 0.52 & 0.80 & $(0.41-1.56)$ \\
\hline$>5 \leq 10$ years old & 272 & 46 & 16.91 & -0.32 & 0.29 & 0.27 & 0.72 & $(0.40-1.29)$ \\
\hline >10 years old & 195 & 38 & 19.49 & $*$ & * & $*$ & $*$ & $*$ \\
\hline Model constant $* *$ & - & - & - & -1.18 & 0.40 & 0.00 & - & - \\
\hline
\end{tabular}

$\mathrm{N}=$ Number of animals; $\mathrm{n}=$ Number of positive animals; $(\%)=$ ositive percentage; $\mathrm{C}(ß)=$ Model coefficient; $\mathrm{SE}=$ Standard error; $\mathrm{P}=\mathrm{p}$-value; $\mathrm{OR}=$ Odds Ratio; $\mathrm{CI}$ = Confidence interval. *Reference category. **Hosmer and Lemeshow test $(\mathrm{p}=0.51)$.

(Pusterla et al. 2000, Coimbra et al. 2005). Thus, equines that have access to pastures that have wetlands, swamps, containing rivers, lakes or ponds, are more likely to be seropositive for $N$. risticii (Perry et al. 1986, Olchowy et al. 1990).

The equids breeding system was not associated with seropositivity for $N$. risticii, however, the equids bred in intensive system had lower frequency of positivity. Although the study Kipper et al. (1992) have not listed the risk factors for $\mathrm{EN}$, the authors point out the equine breeding in stable or intensive systems as a protective factor compared to those bred extensively, since the intensive system decreases the access of animals to pasture areas and the contact with the agent. Some of the studied stabled animals received feed of Brachiaria purpurascens, which develops in the regional wetlands, thus, they could be more likely to be contaminated with intermediate hosts of $N$. risticii. Therefore, the intensive breeding system alone was not a protective factor to the agent in these evaluated animals.
The presence of snails in properties of the lowland region proved to be a risk factor (OR: 2.88; IC:1.33 to 6.24) for the presence of antibodies against $N$. risticii in equids. The $N$. risticii transmission to the equine occurs orally, by accidental ingestion of trematodes infected by this bacterium (Barlough et al. 1998, Park et al. 2003, Pusterla et al. 2000). These trematodes have as intermediate hosts, limnic molluscs and aquatic insects (Pusterla et al. 2000, Chae et al. 2003). The snail species Juga yrekaensis, Elimia livescens and Planorbella subcrenata are indicate in some studies as molluscs involved in the disease transmission chain in the US (Barlough et al. 1998, Kanter et al. 2000, Pusterla et al. 2001). In Brazil, only species from the genre Heleobia sp was found infected by N. risticii in the Southern region of the country (Coimbra et al. 2006). A survey conducted by Thiengo et al. (2001), found several snail genres in the Itaguai micro-region, including Heleobia sp. Thus, the presence of snails that participate in the EN transmission chain in 
Table 4. Frequency of seropositive equids for Neorickettsia risticii according to historical or diarrhea and colic signs, of the presence of equids with laminitis or sensitivities and limb edema or for the presence of equids with fever/ depression in the lowland region of State of Rio de Janeiro

\begin{tabular}{|c|c|c|}
\hline \multirow[t]{2}{*}{ Clinical signs suggestive of infection by $N$. risticii } & \multicolumn{2}{|c|}{ Positive ( $\mathrm{n}=113$ ) } \\
\hline & $\mathrm{n}$ & $(\%)$ \\
\hline \multicolumn{3}{|l|}{ Laminitis/sensitivity in the limbs } \\
\hline Yes & 1 & 0.88 \\
\hline No & 112 & 99.12 \\
\hline \multicolumn{3}{|l|}{ Historic or diarrhea signs / Colic } \\
\hline Yes & 1 & 0.88 \\
\hline No & 112 & 99.12 \\
\hline \multicolumn{3}{|l|}{ Fever / Depression } \\
\hline Yes & 4 & 3.53 \\
\hline No & 109 & 96.46 \\
\hline \multicolumn{3}{|l|}{$\begin{array}{l}\text { At least one of the signs suggestive of } \\
\text { infection by } N \text {. risticii }\end{array}$} \\
\hline Yes & 5 & 4.42 \\
\hline No & 108 & 95.57 \\
\hline
\end{tabular}

this micro-region could justify the higher seropositivity for $N$. risticii in the equine.

No specific factor that could be influencing the seropositivity in equines of the mountain region was possible to point out through multivariate analysis. However, the animal birth origin was the factor with nearest significance $(p=0.06)$, with seropositivity frequency of 6.78 fold higher in equids born outside the property $(7.30 \%)$ compared to those born on the property $(1.25 \%)$. This trend is reinforced by the higher frequency of seropositive equids $(11.0 \%)$ for $N$. risticii on animals with birth origin outside the State of Rio de Janeiro or from unknown birth origins. Dutra et al. (2001) found that animals from farms with no history of the disease introduced into properties with EN history, eventually developed signs suggestive of $N$. risticii infection. Therefore, the results obtained in the mountain region by multivariate analysis indicate the possibility that the positive animals, at least in this region of the State, may have acquired or have had contact with the agent in other regions from within or outside the country.

The molecular diagnosis did not show any animal with N. risticii. The qPCR technique has high sensitivity and specificity, as found in assays targeting this microorganism (Pusterla et al. 2003). The negative result by molecular technique can be explained by the short period of parasitaemia. In an equine experimental infection by $N$. risticii, the parasitaemia period was about 28 days. Thus, despite many of the equids $(n=113)$ have presented antibodies titers to $N$. risticii, does not characterize infection at the time of collection, but immune response due to prior contact with $N$. risticii. Studies have shown that even after long periods of acute infection, some animals may have elevated titers to this agent (Palmer 1993).

The absence of infection in these animals is also confirmed by the absence of association with characteristic clinical signs of EN. The evaluation of clinical parameters and some physiological disorders were considered as an important tool for assist the differential diagnosis of this disease, since animals that presented signs suggestive of infection by $N$. risticii, such as depression, fever, limb edema, dehydration and colic and diarrhea syndrome (Dutta et al. 1985, Mulville 1991, Dutra et al. 2001, Bertin et al. 2013), did not necessarily present infection by this agent.

\section{CONCLUSIONS}

The existence of seropositive equids for Neorickettsia risticii indicates the circulation of this agent in the State of Rio de Janeiro.

The animal age and breeding region are factors associated with seropositivity of animals.

Particularly in the lowland region (Itaguai micro-region) in the State of Rio de Janeiro, the flooded pasture areas, the presence of lakes and rivers in the surroundings and the presence of snails in the equids breeding grazing area are factors associated with equids seropositivity for $N$. risticii.

New and more detailed molecular studies are needed to evaluate the possible circulation of $N$. risticii in equids, as well as to identify possible vectors related to the epidemiological chain of EN in Brazil.

Acknowledgements.- The authors are grateful to Brazilian National Council for Scientific and Technological Development (CNPq) to Coordination for the Improvement of Higher Education Personnel (CAPES) and to Foundation for Research Support of the State of Rio de Janeiro (FAPERJ) for financial support of this project and to the owners of animals that gently proposed to participate in this project.

\section{REFERENCES}

Atwill E.R., Mohammed H.O., Dubovi E. \& Lopes J. 1992. Retrospective evaluation of factors associated with the risk of seropositivity to Ehrlichia risticii in horses in New York state. Am. J. Vet. Res. 53:1931-1934.

Atwill E.R., Mohammed H.O. \& Rua-Domenech D.L.R. 1994. Geographical variation of seropositivity to Ehrlichia risticii (equine monocytic ehrlichosis) of horses in New York state. Equine Vet. J. 26:143-147.

Atwill E.R., Mohammed H.O., Lopez J.W., McCulloch C.E. \& Dubovi E.J. 1996. Cross-sectional evaluation of environmental, host and management factors associated with risk of seropositivity to Ehrlichia risticii in horses of New York state. Am. J. Vet. Res. 57:278-285.

Barlough J.E., Reubel G.H., Madigan J.E., Vredevoe L.K., Miller P.E. \& Rikihisa Y. 1998. Detection of Ehrlichia risticii, the Agent of Potomac Horse Fever, in Freshwater Stream Snails (Pleuroceridae: Juga spp.) from Northern California. Appl. Environ. Microbiol. 64:2888-2893.

Bertin F.R., Reising R., Slovis N.M., Constable P.D. \& Taylor S.D. 2013. Clinical and clinicopathological factors associated with survival in 44 horses with equine neorickettsiosis (Potomac Horse Fever). J. Vet. Intern. Med. 27:1528-1534.

Biswas B., Vemulapalli R. \& Dutta S. 1994. Detection of Ehrlichia risticii from feces of infected horses by immunomagnetic separation and PCR. J. Clin. Microbiol. 32(9):2147-2151.

Breider M.A. \& Henton J.E. 1987.Equine monocytic ehrlichiosis (Potomac Horse Fever). Equine Pratice 9:20-24.

Chae J.-S., Kim M.S. \& Madigan J. 2002. Detection of Neorickettsia (Ehrlichia) risticii in tissues of mice experimentally infected with cercariae of trematodes by in situ hybridization. Vet. Microbiol. 88:233-243.

Chae J.S., Kim E.H., Kim M.S., Kim M.J., Cho Y.H. \& Park B.K. 2003. Prevalence and sequence analyses of Neorickettsia risticii. Ann. N.Y. Acad. Sci. 990:248-256.

Coffman E.A., Abd-Eldaim M. \& Craig L.E. 2008. Abortion in a horse following Neorickettsia risticii infection. J. Vet. Diagn. Invest. 20:827-830.

Coimbra H.S., Schuch L.F.D., Veitenheimer-Mendes I.L. \& Meireles M.C.A. 2005. Neorickettsia (Ehrlichia) risticii no sul do Brasil: Heleobia spp. (Mollusca: Hydrobilidae) e Parapleurolophocecous cercariae (Trema- 
toda: Digenea) como possíveis vetores. Arq. Inst. Biológico, São Paulo, 72(3):325-329.

Coimbra H.S., Fernandes C., Soares M.P., Meireles M.C.A., Radames R. \& Schuch L.F.D. 2006. Erliquiose monocítica equina no Rio Grande do Sul: Aspectos clínicos, anátomo-patológicos e epidemiológicos. Pesq. Vet. Bras. 26:97-101.

Crawford T.B. \& Dilbeck P. 1988. A brief survey of Potomac Horse Fever. Vet. Rev. 8:1.

Dumler J.S., Barbet A.F., Bekker C.P.J., Dasch G.A., Palmer G.H., Ray S.C., Rikihisa Y. \& Rurangirwa F.R. 2001. Reorganization of genera in the families Rickettsiaceace and Anaplasmataceace in the order Rickettsiales; unification of some species of Ehrlichia with Anaplasma, Cowdria with Ehrlichia and Ehrlichia with Neorickettsia, descriptions of six new species combinations and designation of Ehrlichia equi and BHGE agent as subjective synonyms of Ehrlichia phagocytophila. Int. J. Syst. Evol. Micro. 51:2145-2165.

Dutta S.K., Myrup A.C., Rice R.M., Robl M.G. \& Hammond R.C. 1985. Experimental reproduction of Potomac horse fever in horse fever in horses with a newly isolated Ehrlichia organism. J. Clin. Microbiol. 22:265-269.

Dutta S.K., Rice R.M., Hughes T.D., Savage P.K. \& Myrup A.C. 1987. Detection of serum antibodies against Ehrlichia risticii in Potomac Horse Fever by enyzme-linked Immunosorbent assay. Vet. Immunol. Immunopathol. 14:85-92.

Dutra F., Schuch L.D.F., Delucchi E., Curcio B.R., Coimbra H.F., Raffi M.B., Delagostin O. \& Riet-Correa F. 2001. Equine monocytic Ehrlichiosis (Potomac horse fever) in 51 horses in Uruguay and southern Brazil. J. Vet. Diagn. Invest. 13:433-437.

Espy M.J., Uhl J.R., Sloan L.M., Buckwalter S.P., Jones M.F., Vetter E.A., Yao J.D.C., Wengenack N.L., Rosenblatt J.E., Cockerill F.R. \& Smith T.F. 2006. Real-Time PCR in clinical microbiology: applications for routine laboratory Testing. Clin. Microbiol. Rev. 19(1):165-256.

Ferrão C.M., Aboud-Dutra A.E., Lopes R.S., Candeias M.L. \& Gazêta G.S. 2007. Equine Monocytic Ehrlichiosis (EME) in Rio de Janeiro State, Brazil. Arq. Bras. Med. Vet. Zootec. 59(6):1575-1578.

Gibson K.E., Rikihisa Y., Zhang C. \& Martin C. 2005. Neorickettsia risticii is vertically transmitted in the trematode Acanthatrium oregonense and horizontally transmitted to bats. Environ. Microbiol. 7:203-212.

Goetz T.E., Holland C.J., Dawson J.E., Ristic M., Skibbe K., Keegan K.G., Johnson P.J., Schaeffer D.J. \& Baker G.J. 1989. Monthly prevalence (in 1986) of antibody titers against equine monocytic ehrlichiosis in apparently healthy horses in Illinois. Am. J. Vet. Res. 50(11):1936-1939.

Gordon J.C., Bech-Nielsen S., Kohn C., Farrar W., Parsons M. \& Foster W. 1988. An epidemiological investigation of farms with Potomac Horse Fever (Equine Monocytic Ehrlichiosis). Acta Vet. Scand. 84(Suppl.): 319-322.

Holland C.J., Ristic M., Cole A.I., Johnson P., Baker G. \& Goetz T. 1985. Isolation, Experimental transmission, and characterization of causative agent of Potomac Horse Fever. Science 227:522-524.

Kanter M.J., Ohashi N., Fried B., Reed S., Lin Y.C. \& Rikihisa Y. 2000. Analysis of $16 \mathrm{~S}$ rRNA and 51 Kilodalton Antigen gene and transmission in mice of Ehrlichia risticii in Virgulate Trematodes from Elimia livescens snails in Ohio. J. Clin. Microbiol. 38:3349-3358.

Kipper M.L., Traub-Dargatz J.L., Salman M.D. \& Rikihisa Y. 1992. Risk factors for equine monocytic ehrlichiosis seropositivity in horses in Colorado. Prev. Vet. Med. 13(4):251-259.

Knowles R.C., Anderson C.W., Shipley W.D., Whitlock R.H., Perry B.D. \& Davison J.P. 1983. Acute equine diarrhea syndrome (AEDS): a preliminary report. Proc. Am. Assoc. Eq. Pract. 29:353-357.

Long M.T., Goetz T.E., Whiteley H.E., Kakoma I. \& Lock T.E. 1995. Identification of Ehrlichia risticii as the causative agent of two equine abortions following natural maternal infection. J. Vet. Diagn. Invest. 7:201-205.

Madigan J.E., Derock E. \& Lavan R.P. 1989. Clinical significance of a recent serologic survey on the incidence of Potomac horse fever in California. Am. Assoc. Eq. Practit. 34:571-576.

Madigan J.E., Barlough J.E., Rikihisa Y., Wen B., Miller P.E. \& Sampson T.J. 1997. Identification of an enzootic diarrhea ("Shasta River Crud") in northern California as Potomac horse fever. J. Eq. Vet. Sci. 17:270-272.
Moreira L.M.C., Cardoso K.M., Aboud-Dutra A.E., Ferrão C.M. \& Gazêta G.S. 2013. Frequency of Equine Monocytic Ehrlichiosis (EME) in Brazil. Pesq. Vet. Bras. 33(6):697-699.

Mott J., Rikihisa Y., Zhang Y., Reed S.M. \& Yu C.Y. 1997. Comparison of PCR and culture to the indirect fluorescent- antibody test for diagnosis of Potomac horse fever. J. Clin. Microbiol. 35:2215-2219.

Mott J., Muramatsu Y., Seaton E., Martin C., Reed S. \& Rikihisa Y. 2002. Molecular analysis of Neorickettsia risticii in adult aquatic insects in Pennsylvania, in horses infected by ingestion of insects, and isolated in cell culture. J. Clin. Microbiol. 40:690-693.

Mulville P. 1991. Equine Monocytic Erlichiosis (Potomac Horse Fever): a review. Eq. Vet. J. 23(6):400-404.

Oliver O.E. \& Stampfli H. 2006. Acute diarrhea in the adult horse: case example and review. Vet. Clin. North Am., Eq. Pract. 22:73-84.

Olchowy T.W.J., Ames T.R. \& Molitor T.W. 1990. Serodiagnosis of equine monocytic ehrlichiosis in selected groups of horses in Minnesota. J. Am. Vet. Med. Assoc. 15(196):1967-1970.

Palmer J.E., Whitlock R.H. \& Benson C.E. 1986. Equine ehrlichial colitis (Potomac horse fever): recognition of the disease in Pensylvania, New Jersey, New York, Ohio, Idaho and Connecticut. J. Am. Vet. Med. Assoc. 189:197-199.

Palmer J.E. \& Benson C.E. 1988. Oral transmission of Ehrlichia risticii resulting in Potomac Horse Fever. Vet. Rec. 122:635-639.

Palmer J.E. 1993. Potomac horse fever. Vet. Clin. North Am., Eq. Pract. 9:399-410.

Park J., Choi K.S. \& Dumler J.S. 2003. Major surface protein 2 of Anaplasma phagocytophilum facilitates adherence to granulocytes. Infect. Immun. 71:4018-4025.

Perry B.D., Palmer J.E., Troutt H.F., Birch J.B., Morris D., Ehrich M. \& Rikihisa Y. 1986. A case-control study of Potomac horse fever. Prev. Vet. Med. 4:69-82.

Perry B.D., Schmidtmann E.T. \& Rice R.M. 1989. Epidemiology of Potomac horse fever: An investigation into the possible role of non-equine mammals. Vet. Rec. 125:83-86.

Pieel M.C., Finlayson B.L. \& McMahon T.A. 2007. Updated world map of the Köppen-Geiger climate classification. Hydrol. Earth Syst. Sci. 11:1633-1644.

Pusterla N., Leutenegger C.M., Sigrist B., Chae J-S., Lutz H.B. \& Madigan J.E. 2000. Detection and quantitation of Ehrlichia risticii genomic DNA in infected horses and snails by real-time PCR. Vet. Parasitol. 90:129-135.

Pusterla N., Johnson E., Chae J., Pusterla J.B., Derock E. \& Madigan J.E. 2001. Infection rate of Ehrlichia risticii, the agent of Potomac Horse Fever, in freshwater strem snails (Juga yrekaensis) from northern California. Vet. Parasitol. 92:151-156.

Pusterla N., Johnson E.M., Chae J.S. \& Madigan J.E. 2003. Digenetic trematodes Acanthatrium sp. and Lecithodendrium sp., as vectors of Neorickettsia risticii, the agent of Potomac horse fever. J. Helminthol. 77:335-339.

Pusterla N., Madigan J.E. \& Leutenegger C.M. 2006. Real-Time Polymerase Chain Reaction: a novel molecular diagnostic tool for equine infectious diseases. J. Vet. Intern. Med. 20:3-12.

Pusterla N., Hagerty D., Mapes S., Vangeem J., Groves L.T., Dinucci M., Fielding C.L. \& Higgins J.C. 2013. Detection of Neorickettsia risticii from various freshwater snail species collected from a district irrigation canal in Nevada County, California. Vet. J. 197:489-491.

Rikihisa Y., Perry B.D. \& Cordes D.O. 1984. Rickettsial link with acute equine diarrhea. Vet. Rec. 115:550-554.

Rikihisa Y. \& Jiang B.M. 1988. In vitro susceptibilities of Ehrlichia risticii to eight antibiotics. Antimicrob. Agents Chemother. 32(7):986-991.

Rikihisa Y., Reed S.M., Sams R.A., Gordon J.C. \& Pretzman C.I. 1990. Serosurvey of horses with evidence of equine monocytic ehrlichiosis. J. Am. Vet. Med. Assoc. 197(10):1327-1332.

Sampaio I.B.M. 2002. Estatística Aplicada à Experimentação Animal. 2aa ed. Editora, FEPMVZ, Belo Horizonte. 265p.

Thiengo S.C., Fernandez M.A. Boaventura M.F., Grault C., Silva H.F., Mattos A.C. \& Santos S.B. 2001. Freshwater snails and Schistosomiasis mansoni in the State of Rio de Janeiro, Brazil. I. Metropolitan mesoregion. Mem. Inst. Oswaldo Cruz 99(3):275-280. 